\title{
Article \\ Adaptive Laboratory Evolution for Multistress Tolerance, including Fermentability at High Glucose Concentrations in Thermotolerant Candida tropicalis
}

\author{
Koudkeo Phommachan ${ }^{1}$, Chansom Keo-oudone ${ }^{2}$, Mochamad Nurcholis ${ }^{3}$ (D, Nookhao Vongvilaisak ${ }^{2}$, \\ Mingkhuan Chanhming ${ }^{2}$, Vanhnavong Savanhnaly ${ }^{2}$, Somchanh Bounphanmy ${ }^{2}$, Minenosuke Matsutani ${ }^{4,+}$, \\ Tomoyuki Kosaka ${ }^{1,4,5}(\mathbb{D})$, Savitree Limtong ${ }^{6}(\mathbb{D})$ and Mamoru Yamada $1,4,5, * \mathbb{D}$
}

check for updates

Citation: Phommachan, K.; Keo-oudone, C.; Nurcholis, M.; Vongvilaisak, N.; Chanhming, M.; Savanhnaly, V.; Bounphanmy, S.; Matsutani, M.; Kosaka, T.; Limtong, S.; et al. Adaptive Laboratory Evolution for Multistress Tolerance, including Fermentability at High Glucose Concentrations in Thermotolerant Candida tropicalis. Energies 2022, 15, 561. https:// doi.org/10.3390/en15020561

Academic Editors: Francesco Frusteri and Dino Musmarra

Received: 11 November 2021

Accepted: 9 January 2022

Published: 13 January 2022

Publisher's Note: MDPI stays neutral with regard to jurisdictional claims in published maps and institutional affiliations.

Copyright: (C) 2022 by the authors. Licensee MDPI, Basel, Switzerland. This article is an open access article distributed under the terms and conditions of the Creative Commons Attribution (CC BY) license (https:// creativecommons.org/licenses/by/ $4.0 /)$
1 Graduate School of Sciences and Technology for Innovation, Yamaguchi University, Yamaguchi 753-8515, Japan; koudkeo.phommachan@gmail.com (K.P.); tkosaka@yamaguchi-u.ac.jp (T.K.)

2 Department of Biology, Faculty of Natural Science, National University of Laos, Vientiane 7322, Laos; chansom_k@yahoo.com (C.K.-o.); nookhao.vong@gmail.com (N.V.); Mingkhuanc@gmail.com (M.C.); Cocosavanhnaly@gmail.com (V.S.); sbounphanmy@nuol.edu.la (S.B.)

3 Department of Food Science and Technology, Faculty of Agricultural Technology, Brawijaya University, Malang 65145, Indonesia; cholis_federer@yahoo.co.id

4 Department of Biological Chemistry, Faculty of Agriculture, Yamaguchi University, Yamaguchi 753-8515, Japan; mm207299@nodai.ac.jp

5 Research Center for Thermotolerant Microbial Resources, Yamaguchi University, Yamaguchi 753-8315, Japan

6 Department of Microbiology, Faculty of Science, Kasetsart University, Bangkok 10900, Thailand; fscistl@ku.ac.th

* Correspondence: m-yamada@yamaguchi-u.ac.jp

† Present address: Minenosuke Matsutani, NODAI Genome Research Center, Tokyo University of Agriculture, Tokyo 156-8502, Japan.

Abstract: Candida tropicalis, a xylose-fermenting yeast, has the potential for converting cellulosic biomass to ethanol. Thermotolerant C. tropicalis X-17, which was isolated in Laos, was subjected to repetitive long-term cultivation with a gradual increase in temperature (RLCGT) in the presence of a high concentration of glucose, which exposed cells to various stresses in addition to the high concentration of glucose and high temperatures. The resultant adapted strain demonstrated increased tolerance to ethanol, furfural and hydroxymethylfurfural at high temperatures and displayed improvement in fermentation ability at high glucose concentrations and xylose-fermenting ability. Transcriptome analysis revealed the up-regulation of a gene for a glucose transporter of the major facilitator superfamily and genes for stress response and cell wall proteins. Additionally, hydropathy analysis revealed that three genes for putative membrane proteins with multiple membrane-spanning segments were also up-regulated. From these findings, it can be inferred that the up-regulation of genes, including the gene for a glucose transporter, is responsible for the phenotype of the adaptive strain. This study revealed part of the mechanisms of fermentability at high glucose concentrations in C. tropicalis and the results of this study suggest that RLCGT is an effective procedure for improving multistress tolerance.

Keywords: Candida tropicalis; fermenting yeast; adaptive laboratory evolution; fermentability at high glucose concentrations; multistress tolerance

\section{Introduction}

Solutions for the problems of global warming and the unsustainability of future energy supplies are crucial for continued economic development [1,2]. Much interest has been shown in biomass as carbon sources for biofuel production due to the environmentally friendly low carbon emissions of biofuels [3-6]. Biomass conversion has been performed by fermentation or other biomass utilization technologies, particularly fast pyrolysis. For example, Hamouda et al. [7] converted sugarcane molasses by fermentation with 
Candida tropicalis HSC-24 to ethanol. Li et al. [3,4] cultivated Desmodesmus sp. in anaerobic digested wastewater and then converted it by fast pyrolysis to biofuel. In recent years, increasing interest has been shown in lignocellulose biomass as renewable and sustainable energy resources. Bioethanol, a biofuel from lignocellulosic biomass, is gaining increasing attention as an alternative fuel due to fluctuations in oil prices, reduced oil reserves, and important environmental issues associated with greenhouse gas emissions [8-13]. Lignocellulose is composed of three major carbohydrate polymers: cellulose, hemicelluloses and lignin $[1,8,9]$. Hemicellulose hydrolysates contain xylose as an abundant sugar $[14,15]$. Therefore, the utilization of lignocellulosic biomass as a substrate for ethanol production requires yeast strains that are capable of efficiently converting xylose to ethanol. Nevertheless, due to glucose repression, the efficient co-fermentation of glucose and xylose is a major challenge in achieving the conversion of lignocellulosic biomass to biofuels [15]. In addition, lignocellulose has a complex molecular structure in which chains of the three carbohydrate polymers are intertwined, requiring a pretreatment step to obtain sugars for fermentation. The steps for biochemical conversion of lignocellulose to useful products such as ethanol include (1) pretreatment to open, unique and cumbersome structures, (2) enzymatic hydrolysis for the saccharification of carbohydrate polymers and (3) the microbial fermentation of hydrolyzed sugars [1,9]. However, additional lignocellulose-derived compounds, such as aliphatic acids, furan derivatives and phenolic compounds, can be generated during pretreatment and have inhibitory effects on enzymatic performance. These inhibitors reduce the yield of fermentable sugars and adversely affect subsequent ethanol productions $[1,16,17]$.

Furthermore, during the ethanol fermentation process, yeast cells are simultaneously and continuously exposed to various stresses, such as high concentrations of sugar substrates, final products including ethanol and elevated temperature, in addition to the lignocellulose-derived compounds [18-24]. Specifically, fermentation with high concentrations of sugar to obtain high yields of ethanol exacerbates the negative effects of stress on both the substrate and the product [25]. In general, compared to Saccharomyces cerevisiae, xylose-fermenting yeasts are sensitive to high concentrations of glucose. As with the development of various stress-tolerant strains [26,27], improving the durability of xylosefermenting yeast strains to high concentrations of glucose is important for the efficient conversion of lignocellulosic biomass.

Candida tropicalis X-17, which was isolated in Laos, is a thermotolerant xylose-fermenting yeast with similar growth rates in glucose and xylose media. However, similarly to most other xylose-fermenting yeasts, this strain is sensitive to high concentrations of glucose. In this study, we attempted to improve the sensitiveness of the strain to high concentrations of glucose by repetitive long-term cultivation with a gradual increase in temperature (RLCGT) (Pattanakittivorakul et al., submitted) in the presence of a high concentration of glucose. RLCGT is an efficient laboratory adaptation procedure for the development of adapted strains because it allows cells to be exposed to various stresses, such as stresses from metabolites including ethanol and organic acids, by-products formed by chemical reactions, nutrient starvation, high temperatures and oxidative stress. As adapted strains were successfully obtained by laboratory adaptation procedures in the presence of main stress factors of high concentrations of substrate [26] or high temperatures [27], RLCGT containing these factors may have advantages for acquiring adapted strains compared to the previous procedures. As expected, an adapted strain isolated by RLCGT in the presence of $200 \mathrm{~g} \cdot \mathrm{L}^{-1}$ glucose was found to be resistant not only to high concentrations of glucose but also to other stresses. This was the first trial of RLCGT performed in the presence of high levels of glucose, and its success may encourage us to further challenge cell capacity improvement for achieving a cost-effective method for lignocellulosic bioethanol production. 


\section{Materials and Methods}

\subsection{Yeast Strains}

The yeast strains used in this study were thermotolerant, xylose-fermenting C. tropicalis X-17, its derivative strain and thermotolerant Kluyveromyces marxianus DMKU 3-1042 [28]. C. tropicalis X-17 was isolated from a fruit by the non-enrichment method in Laos and its isolation with other strains will be reported elsewhere.

\subsection{Media and Growth Conditions}

YPD medium $\left(10 \mathrm{~g} \cdot \mathrm{L}^{-1}\right.$ yeast extract, $20 \mathrm{~g} \cdot \mathrm{L}^{-1}$ peptone and $20 \mathrm{~g} \cdot \mathrm{L}^{-1}$ glucose $)$ was used for pre-culture at $30^{\circ} \mathrm{C}$ under a shaking condition at $160 \mathrm{rpm}$ and $\mathrm{YP}$ medium $\left(10 \mathrm{~g} \cdot \mathrm{L}^{-1}\right.$ yeast extract, $20 \mathrm{~g} \cdot \mathrm{L}^{-1}$ peptone) containing $200 \mathrm{~g} \cdot \mathrm{L}^{-1}$ glucose was used for adaptation. YP agar plates supplemented with $20 \mathrm{~g} \cdot \mathrm{L}^{-1}$ of mannose, galactose, xylose or sucrose were named YPMan, YPGal, YPXyl and YPSuc, respectively. In some cases, 2-deoxyglucose (2-DOG) as a glucose analog was further supplemented. Fermentation was carried out in YP medium supplemented with $160 \mathrm{~g} \cdot \mathrm{L}^{-1}$ glucose (YP16D), $20 \mathrm{~g} \cdot \mathrm{L}^{-1}$ glucose (YP2D), $20 \mathrm{~g} \cdot \mathrm{L}^{-1}$ xylose (YP2X), $50 \mathrm{~g} \cdot \mathrm{L}^{-1}$ xylose (YP5X), both $2 \mathrm{~g} \cdot \mathrm{L}^{-1}$ glucose and $20 \mathrm{~g} \cdot \mathrm{L}^{-1}$ xylose (YP0.2D2X), $20 \mathrm{~g} \cdot \mathrm{L}^{-1}$ glucose and $20 \mathrm{~g} \cdot \mathrm{L}^{-1}$ xylose (YP2D2X), $40 \mathrm{~g} \cdot \mathrm{L}^{-1}$ glucose and $20 \mathrm{~g} \cdot \mathrm{L}^{-1}$ xylose (YP4D2X), $20 \mathrm{~g} \cdot \mathrm{L}^{-1}$ glucose and $50 \mathrm{~g} \cdot \mathrm{L}^{-1}$ xylose (YP2D5X) xylose, and $50 \mathrm{~g} \cdot \mathrm{L}^{-1}$ glucose and $50 \mathrm{~g} \cdot \mathrm{L}^{-1}$ xylose (YP5D5X) as a carbon source.

\subsection{Evolutionary Adaptation by RLCGT}

Evolutionary adaptation was performed by RLCGT (Pattanakittivorakul et al., submitted) in the presence of a high concentration of glucose. C. tropicalis X-17 cells were pre-cultured in YPD medium at $30{ }^{\circ} \mathrm{C}$ for $16 \mathrm{~h}$ under a shaking condition at $160 \mathrm{rpm}$. The pre-culture was inoculated into $5 \mathrm{~mL}$ of YP liquid medium containing $200 \mathrm{~g} \cdot \mathrm{L}^{-1} \mathrm{glu}-$ cose in five test tubes at an optical density $\left(\mathrm{OD}_{660}\right)$ of 0.1 and subjected to long-term cultivation at $40{ }^{\circ} \mathrm{C}$ under a shaking condition at $100 \mathrm{rpm}$ for 7 days. After that, the cells were transferred to a fresh medium at $\mathrm{OD}_{660}$ of 0.1 and cultivation was repeated under the same conditions. After cultivation twice at $40{ }^{\circ} \mathrm{C}$, at the second time the culture was transferred to a fresh medium and cultivated at $41^{\circ} \mathrm{C}$ and $100 \mathrm{rpm}$ for 7 days. Cultivation was repeated with a gradual increase in temperature from $40^{\circ} \mathrm{C}$ to $44.5^{\circ} \mathrm{C}$ (Figure S1). Cultivation was performed two or three times at each temperature. Finally, the RLCGT culture that survived at $44.5^{\circ} \mathrm{C}$ was streaked on an YPD plate and a single colony was isolated as an adapted strain. The stability of the adaptive strain was tested by transferring it from low glucose concentration plates to high glucose concentration media several times, and a reproduced phenotype of growth was observed.

\subsection{Analysis of Stress Resistance and Effects of 2-DOG on Utilization of Various Sugars}

Cells grown in YPD medium at $30{ }^{\circ} \mathrm{C}$ under a shaking condition at $160 \mathrm{rpm}$ for $16 \mathrm{~h}$ were washed and suspended in sterile distilled water with adjustment of $\mathrm{OD}_{660}$ to 1 . The cell suspension was 10-fold serially diluted and spotted onto YP agar plates supplemented with $35 \%$ of glucose, $6 \%$ ethanol, $10 \mathrm{mM}$ furfural or $15 \mathrm{mM} \mathrm{HMF}$ at a final concentration. These plates were then incubated at different temperatures for $48 \mathrm{~h}$. The serially diluted cell suspensions were also spotted on YPD, YPMan, YPGal, YPXyl or YPSuc agar plates with or without $0.01 \%, 0.05 \%$ or $0.1 \% 2-D O G$. These plates were then incubated at $30^{\circ} \mathrm{C}$ for $48 \mathrm{~h}$.

\subsection{Analysis of Ethanol Fermentation}

To examine abilities for ethanol production and glucose and xylose utilization, yeast strains were pre-cultured in YPD medium at $30{ }^{\circ} \mathrm{C}$ under a shaking condition at $160 \mathrm{rpm}$ for $16 \mathrm{~h}$. The pre-culture was inoculated into a 100-mL flask containing $30 \mathrm{~mL}$ of YP16D, YP5X or YP2D2X at $\mathrm{OD}_{660}$ of 0.1 , followed by incubation at different temperatures. Cell density was determined by measurement on a UV-VIS spectrophotometer (Shimadzu, Kyoto, Japan). Fermentation parameters were analyzed on a high-performance liquid 
chromatography (HPLC) system (Hitachi, Tokyo, Japan) consisting of a Hitachi Model D-2000 Elite HPLC system Manager, L-2130 column oven, L-2130 pump, L-2200 autosampler and L-2490 RI detector equipped with a GL-C610H-S gel pack column at $60{ }^{\circ} \mathrm{C}$ with $0.5 \mathrm{~mL} / \mathrm{min}$ eluent of $0.1 \%$ phosphoric acid.

\subsection{Preparation of Genomic DNA, Genomic Sequencing and Determination of Mutations}

The genome DNAs of $C$. tropicalis $\mathrm{X}-17.2 \mathrm{~b}$ and $\mathrm{C}$. tropicalis $\mathrm{X}-17$ as the parent strain were extracted as described previously [29] from cells grown in YPD medium for $18 \mathrm{~h}$ under a shaking condition at $30{ }^{\circ} \mathrm{C}$ and further purified using a Genomic-tip 20 kit (Qiagen, Hilden, Germany) according to the manufacturer's instructions. In order to identify the mutation sites of $X-17.2 b$, we performed genome sequencing of both $X-17$ and $X-17.2 b$ using the Illumina NextSeq 500 platform and mapped this against the complete genome sequence of C. tropicalis MYA-3404, which is available at DDBJ/EMBL/GenBank, accession number GCA_000006335.3. The quantity and purity of genomic DNA were assessed by using a Qubit 2.0 Fluorometer with a Qubit dsDNA BR Assay Kit (Thermo Fisher Scientific, Inc., Waltham, MA, USA) and a NanoDrop One spectrophotometer (Thermo Fisher Scientific). A genomic DNA library for Illumina sequencing was prepared using NEBNext Ultra II DNA Library Prep Kit for Illumina according to the manufacturer's instructions with 9 PCR cycles (New England BioLabs Inc., Ipswich, MA, USA). Genome sequencing was carried out with Illumina NextSeq 500 platform. A total of 27,724,872 and 28,307,864 sequence pairs of 76-bp paired-end nucleotide reads from $X-17$ and $X-17.2 b$, respectively, were obtained, which yielded approximately 144 -fold and 147-fold sequence coverage, respectively. The Illumina sequencing reads of both $\mathrm{X}-17$ and $\mathrm{X}-17.2 \mathrm{~b}$ were aligned with the MYA-3404 genome sequence using BWA [30]. Different sequence sites in both strains were searched for using the Genome Analysis Toolkit (GATK) v3.6-0-g89b7209 [31]. Accession numbers of sequence data are DRR328071 for X-17 and DRR32807 for X-17.2b.

\subsection{RNA-Seq Analysis}

RNA for RNA-Seq analysis was prepared, as described previously [32]. The parental strain X-17 and adapted strain X-17.2b were cultivated in $30 \mathrm{~mL}$ of YP16D medium in a $100-\mathrm{mL}$ Erlenmeyer flask on a rotary shaker at $100 \mathrm{rpm}$ and $37^{\circ} \mathrm{C}$ for $12 \mathrm{~h}$. The cells were harvested by centrifugation at $5000 \mathrm{rpm}$ for $5 \mathrm{~min}$ at $4{ }^{\circ} \mathrm{C}$ and subjected to an RNA preparation process. RNA was prepared by a modified procedure on the basis of the procedure reported previously [33]. The RNA samples then were subjected to RNase-free DNase treatment. All RNA samples were purified by using an RNeasy plus mini kit (QIAGEN, Hilden, Germany) according to the protocol provided by the supplier.

The purified RNA samples were analyzed on an Illumina NextSeq at the Research Center of Yamaguchi University. The detailed procedure for RNA-Seq has been described previously [34]. The sequencing results were analyzed using CLC Genomic Workbench version 10.1.1. All mapped reads at exons were counted, and the numbers were converted to unique exon reads. The unique exon reads $(15,531,789$ and $20,065,386)$ from two biological replicates of $\mathrm{X}-17.2 \mathrm{~b}$ were compared to those $(17,191,058$ and $20,374,059)$ of the parental strain. Accession numbers of sequence data are DRR324097 and DRR324098 for X-17 and DRR324099 and DRR324100 for X-17.2b.

Gene expression profiles of $\mathrm{X}-17.2 \mathrm{~b}$ and the parental strain were compared to find differentially expressed genes (DEGs) based on unique exon read values from CLC genomic workbench outputs using DESeq2 R package [35]. The resulting $p$-values were adjusted using Benjamin-Hochberg's method for controlling the false discovery rate. Genes with adjusted $p$-values less than $0.01\left(P_{\text {adj }}<0.01\right)$ and $\log _{2}$ (fold change) values greater than 2 or lower than -2 were assigned as significant DEGs.

Functions of significantly up-regulated or down-regulated genes were searched by BLAST and Uni-Prot. 


\subsection{Hydropathy Analysis}

Hydropathy analysis was performed by using the algorithm of Kyte and Doolittle [36] with the normalized consensus hydrophobicity value of Eisenberg [37] and a window of 21 amino acids. The predicted amino acid sequences of putative transporters were plotted using the ExPASy-Expasy website (https:/ / web.expasy.org/protscale/, 10 December 2021). Sequences with a hydrophobicity value of more than 0.42 were identified as membranespanning segments.

\section{Results}

\subsection{Evolutionary Adaptation of C. tropicalis X-17 by RLCGT}

In order to improve the sensitivity of $C$. tropicalis $\mathrm{X}-17$ to high glucose concentrations, we applied the RLCGT established previously to acquire multi-stress tolerance with the modification of addition of a high concentration of glucose; that is, the strain was subjected to RLCGT in the presence of $200 \mathrm{~g} \cdot \mathrm{L}^{-1}$ glucose under a shaking condition (Figure S1). The treatment was initiated at $40^{\circ} \mathrm{C}$ after cells had been inoculated into five different test tubes, and cell survival was observed by monitoring the optical density at $660 \mathrm{~nm}\left(\mathrm{OD}_{660}\right)$. Three of the five tubes showed no increase in $\mathrm{OD}_{600}$ at $43.5^{\circ} \mathrm{C}$ and one tube showed no increase at $44.5^{\circ} \mathrm{C}$. Cells in the remaining tube after incubation at $44.5^{\circ} \mathrm{C}$ three times were spread on an agar plate, and one larger colony named $\mathrm{X}-17.2 \mathrm{~b}$ was selected. $\mathrm{X}-17.2 \mathrm{~b}$ was then used as an adapted strain in the following experiments.

\subsection{Effects of Various Stresses on Growth of $X-17.2 b$}

During RLCGT, yeast cells were expected to be exposed to various stresses, as in a general fermentation process [18-21]. Effects of various stresses on growth of $X-17.2 b$ were therefore examined by spot tests (Figure 1).

(a)

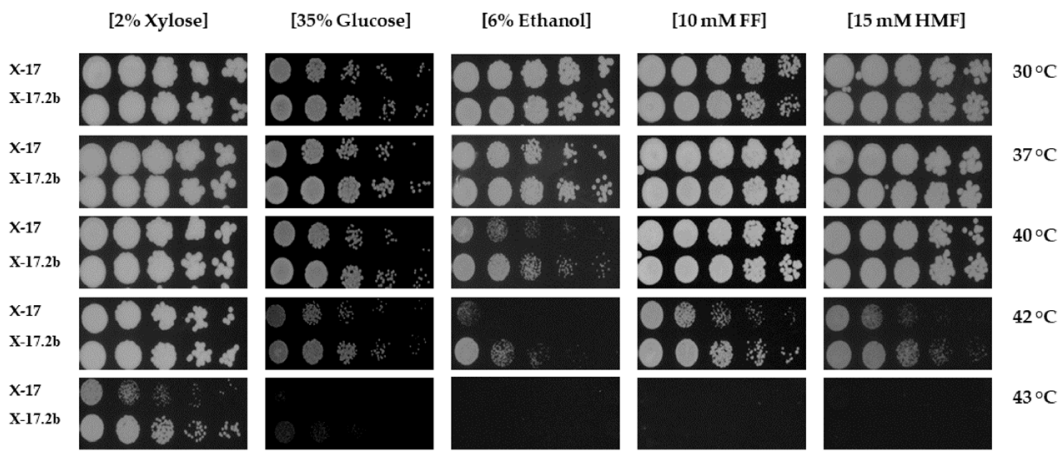

(b)

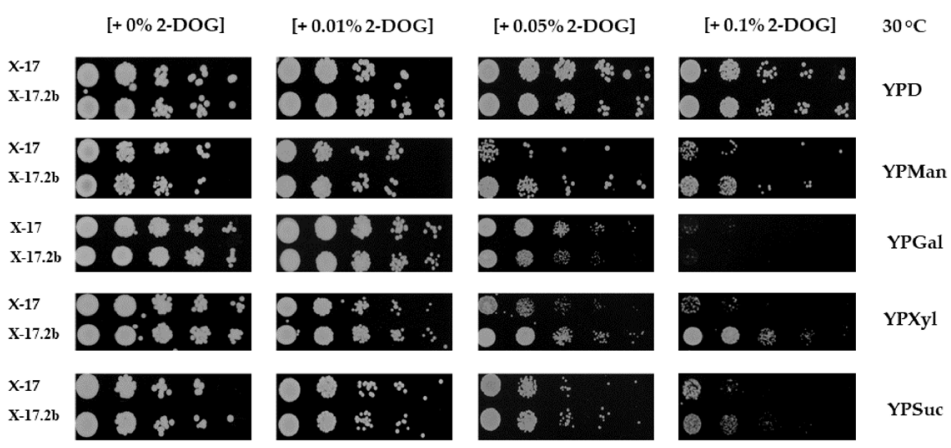

Figure 1. Stress resistance and effects of 2-DOG on sugar utilization of $C$. tropiclis $\mathrm{X}-17$ and adapted strain C. tropiclis X-17.2b. Serially diluted cells were spotted onto (a) YP2X, YP35D and YP2X agar plates supplemented with $6 \%$ ethanol, $10 \mathrm{mM}$ furfural or $15 \mathrm{mM} \mathrm{HMF}$ and (b) YPD, YPMan, YPGal, YPXyl and YPSuc agar plates supplemented with or without $0.01 \%, 0.05 \%$ or $0.1 \%$ 2-DOG. The plates were incubated (a) at $30^{\circ} \mathrm{C}, 37^{\circ} \mathrm{C}, 40^{\circ} \mathrm{C}, 42^{\circ} \mathrm{C}$ and $43^{\circ} \mathrm{C}$ and (b) at $30^{\circ} \mathrm{C}$ for $48 \mathrm{~h}$. 
Pre-cultures were serially diluted and spotted onto YP agar plates supplemented with $35 \%$ glucose, $2 \%$ xylose, $6 \%$ ethanol, $10 \mathrm{mM}$ furfural or $10 \mathrm{mM}$ hydroxymethylfurfural and incubated at five different temperatures for $48 \mathrm{~h}$. When compared with $\mathrm{X}-17$ as the parental strain, X-17.2b showed better growth after 48 -h incubation at $40{ }^{\circ} \mathrm{C}, 42{ }^{\circ} \mathrm{C}$ or $43^{\circ} \mathrm{C}$ (Figure 1a). Similarly, X-17.2b showed better growth than that of the parental strain on various sugar-containing plates supplemented with $0.05 \%$ or $0.1 \%$ 2-DOG except for galactose-containing plates (Figure $1 \mathrm{~b}$ ), indicating that $\mathrm{X}-17.2 \mathrm{~b}$ may exhibit a relatively weak glucose repression in cases of mannose, xylose and sucrose. These findings suggest that the adapted strain had resistance to various stresses at high temperatures.

\subsection{Ethanol Fermentation Ability of X-17.2b}

Efficient ethanol fermentation with high concentrations of sugars at high temperatures is crucial for industrial applications. The ethanol fermentation ability of $\mathrm{X}-17.2 \mathrm{~b}$ was therefore examined in the presence of high concentrations of glucose at high temperatures (Figure 2). Pre-culture was inoculated into YP medium containing $160 \mathrm{~g} \cdot \mathrm{L}^{-1}$ glucose and cultured at $37^{\circ} \mathrm{C}, 40^{\circ} \mathrm{C}$ and $42{ }^{\circ} \mathrm{C}$ for $72 \mathrm{~h}$, and fermentation parameters were compared with those of the parental strain and K. marxianus DMKU 3-1042, which is an efficient fermenting yeast at high temperatures [38].

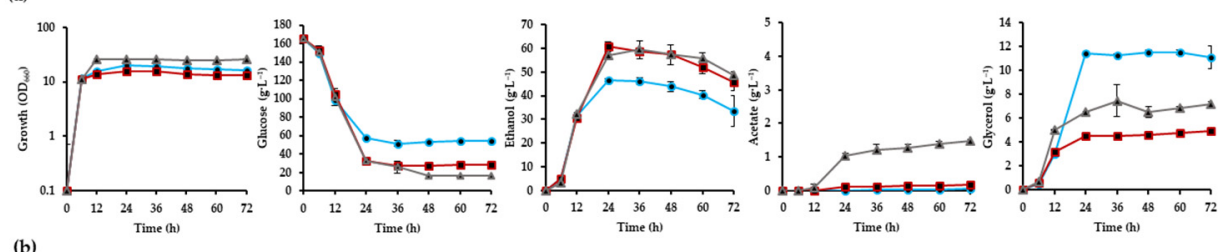

(b)

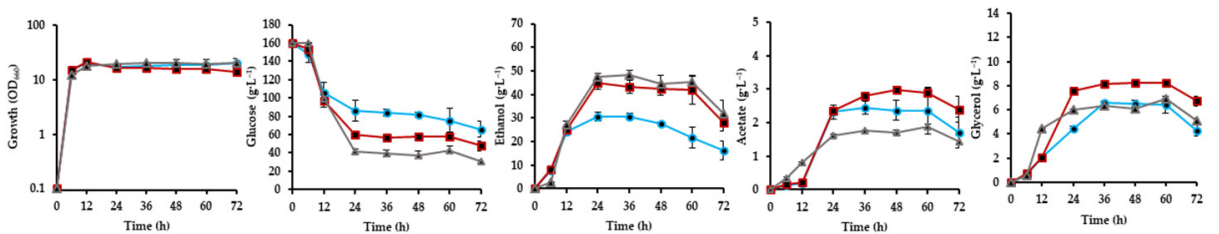

(c)

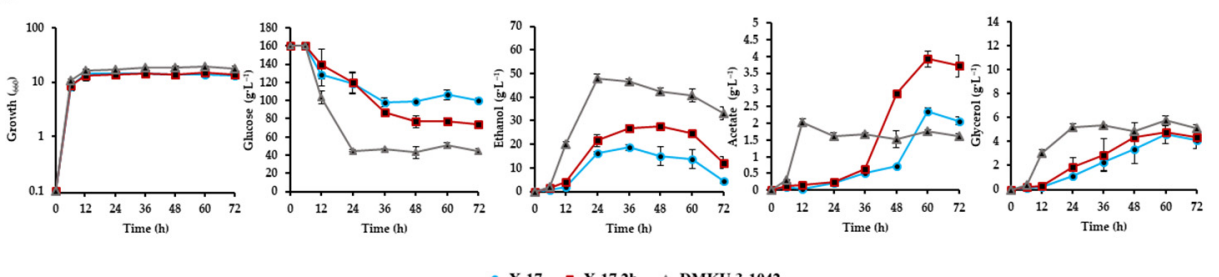

Figure 2. Growth and metabolite profiles of $C$. tropiclis $X-17$ (filled circles), adapted strain C. tropicalis $\mathrm{X}-17.2 \mathrm{~b}$ (filled squares) and K. marxianus DMKU 3-1042 (filled triangles). Cells are grown in YP media containing $160 \mathrm{~g} \cdot \mathrm{L}^{-1}$ glucose at (a) $37{ }^{\circ} \mathrm{C}$, (b) $40{ }^{\circ} \mathrm{C}$ and (c) $42{ }^{\circ} \mathrm{C}$ under a shaking condition at $100 \mathrm{rpm}$, and samples were taken at $6 \mathrm{~h}$ and every $12 \mathrm{~h}$ until $72 \mathrm{~h}$ of incubation. Bars represent the $\pm \mathrm{SD}$ of values from experiments performed in triplicate.

At $37^{\circ} \mathrm{C}, \mathrm{X}-17.2 \mathrm{~b}$ showed levels of glucose consumption and ethanol production similar to those of DMKU 3-1042 and much higher than those of the parental strain. Maximum ethanol concentrations of X-17.2b, X-17 and DMKU 3-1042 were $60.7 \mathrm{~g} \cdot \mathrm{L}^{-1}$, $46.5 \mathrm{~g} \cdot \mathrm{L}^{-1}$ and $56.9 \mathrm{~g} \cdot \mathrm{L}^{-1}$, respectively. Interestingly, $\mathrm{X}-17.2 \mathrm{~b}$ and $\mathrm{X}-17$ produced almost no acetate and $\mathrm{X}-17.2 \mathrm{~b}$ showed much lower glycerol accumulation than that of the parental strain. With increases in temperature, $40{ }^{\circ} \mathrm{C}$ and $42{ }^{\circ} \mathrm{C}$, the glucose consumption and ethanol production levels of $\mathrm{X}-17.2 \mathrm{~b}$ were lower than those of DMKU 3-1042 but still higher than those of the parental strain. Maximum ethanol concentrations of $\mathrm{X}-17.2 \mathrm{~b}$, $\mathrm{X}-17$ and DMKU 3-1042 were $44.9 \mathrm{~g} \cdot \mathrm{L}^{-1}, 30.5 \mathrm{~g} \cdot \mathrm{L}^{-1}$ and $47.6 \mathrm{~g} \cdot \mathrm{L}^{-1}$, respectively, at $40^{\circ} \mathrm{C}$, and $27.8 \mathrm{~g} \cdot \mathrm{L}^{-1}, 14.9 \mathrm{~g} \cdot \mathrm{L}^{-1}$ and $42.3 \mathrm{~g} \cdot \mathrm{L}^{-1}$, respectively, at $42{ }^{\circ} \mathrm{C}$. The acetate levels of 
$\mathrm{X}-17.2 \mathrm{~b}$ were higher than those of the parental strain, and the acetate production of $\mathrm{X}-17.2 \mathrm{~b}$ and X-17 was delayed compared to that of DMKU 3-1042. These results suggest that the adapted strain can achieve efficient fermentation with high concentrations of glucose at high temperatures.

Next, fermentation ability with $50 \mathrm{~g} \cdot \mathrm{L}^{-1}$ xylose of $\mathrm{X}-17.2 \mathrm{~b}$ was examined at $35^{\circ} \mathrm{C}$, $37^{\circ} \mathrm{C}$ and $42{ }^{\circ} \mathrm{C}$ (Figure 3). The adapted strain showed higher ethanol concentrations at $36 \mathrm{~h}$ to $60 \mathrm{~h}$ than those of the parental strain, and both strains accumulated large amounts of xylitol. Maximum ethanol concentrations of $\mathrm{X}-17.2 \mathrm{~b}$ at $35^{\circ} \mathrm{C}, 37^{\circ} \mathrm{C}$ and $42{ }^{\circ} \mathrm{C}$ were $5.34 \mathrm{~g} \cdot \mathrm{L}^{-1}, 4.40 \mathrm{~g} \cdot \mathrm{L}^{-1}$ and $3.0 \mathrm{~g} \cdot \mathrm{L}^{-1}$, respectively. Notably, C. tropicalis $\mathrm{X}-17$ and its adapted strain consumed xylose and produced ethanol faster and in larger amounts than did K. marxianus DMKU 3-1042 and accumulated much lower concentrations of acetate at $35^{\circ} \mathrm{C}$ and $37^{\circ} \mathrm{C}$ (Figure $\left.3 \mathrm{a}, \mathrm{b}\right) . \mathrm{X}-17.2 \mathrm{~b}$ consumed xylose and produced a larger amount of ethanol than did X-17 even at $42{ }^{\circ} \mathrm{C}$ (Figure 3c). Therefore, it is likely that the adapted strain has enhanced xylose-fermentation ability.

(a)
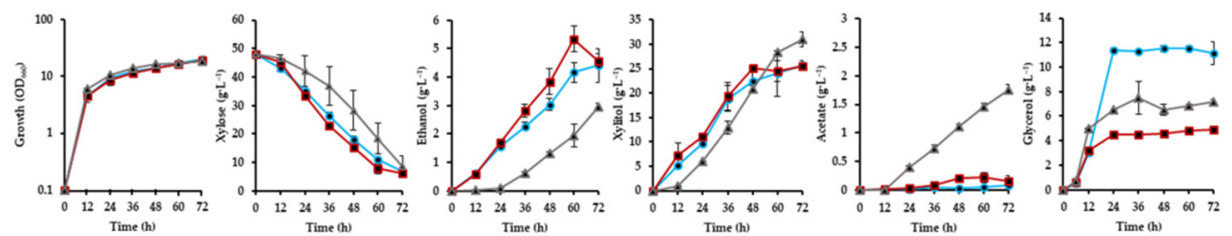

(b)
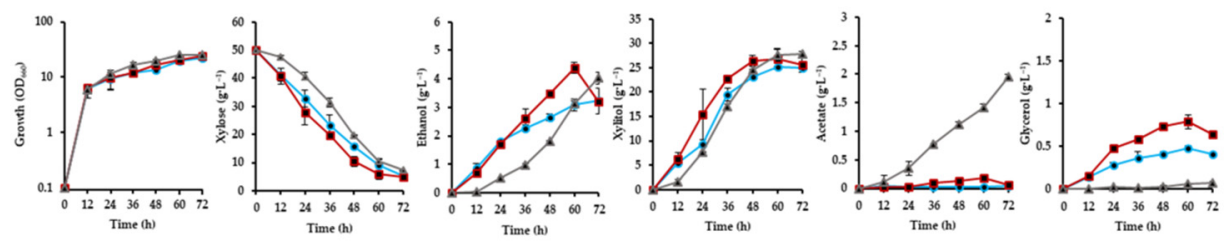

(c)
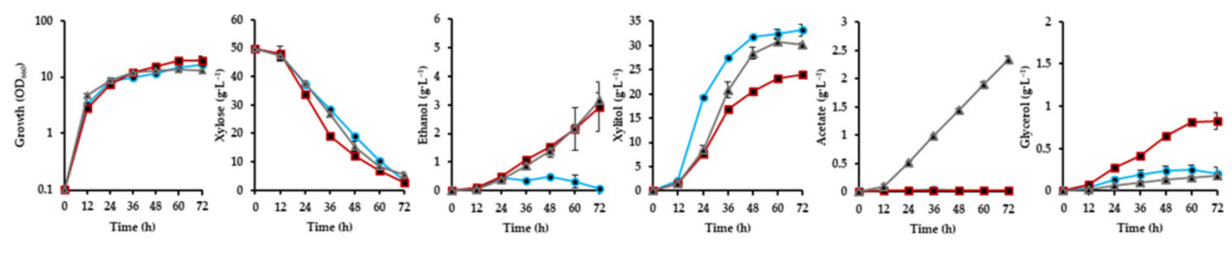

$\rightarrow \mathrm{X}-17 \rightarrow \mathrm{X}-17.2 \mathrm{~b} \neq \mathrm{DMKU} 3-1042$

Figure 3. Growth and metabolite profiles of $C$. tropiclis $\mathrm{X}-17$ (filled circles), adapted strain C. tropicalis $\mathrm{X}-17.2 \mathrm{~b}$ (filled squares) and K. marxianus DMKU 3-1042 (filled triangles). Cells were grown in YP media containing $50 \mathrm{~g} \cdot \mathrm{L}^{-1}$ xylose at (a) $35^{\circ} \mathrm{C}$, (b) $37^{\circ} \mathrm{C}$ and (c) $42{ }^{\circ} \mathrm{C}$ under a shaking condition at $100 \mathrm{rpm}$, and samples were taken every $12 \mathrm{~h}$ until $72 \mathrm{~h}$ of incubation. Bars represent the \pm SD of values from experiments performed in triplicate.

Fermentation with mixed sugars of xylose and glucose was also carried out at $37^{\circ} \mathrm{C}$ (Figure 4), considering the optimum temperatures for ethanol production in the case of glucose and xylose (Figures 2 and 3). In the case of $20 \mathrm{~g} \cdot \mathrm{L}^{-1}$ xylose and $2 \mathrm{~g} \cdot \mathrm{L}^{-1}$ glucose, $\mathrm{X}-17.2 \mathrm{~b}$ and $\mathrm{X}-17$ demonstrated patterns of xylose utilization that were similar to and ethanol production levels that were higher than those in the case of only $20 \mathrm{~g} \cdot \mathrm{L}^{-1}$ xylose, and they demonstrated maximum ethanol concentrations of $3.77 \mathrm{~g} \cdot \mathrm{L}^{-1}$ and $2.82 \mathrm{~g} \cdot \mathrm{L}^{-1}$, respectively (Figure 4a,b). On the other hand, DMKU 3-1042 produced a lower concentration of ethanol and a higher concentration of xylitol than those in the case of only $20 \mathrm{~g} \cdot \mathrm{L}^{-1}$ xylose. In the case of $20 \mathrm{~g} \cdot \mathrm{L}^{-1}$ xylose and $20 \mathrm{~g} \cdot \mathrm{L}^{-1}$ glucose, $\mathrm{X}-17.2 \mathrm{~b}$ and X-17 demonstrated slightly delayed xylose utilization and DMKU 3-1042 demonstrated greatly reduced xylose utilization compared to those in the case of only $20 \mathrm{~g} \cdot \mathrm{L}^{-1}$ xylose (Figure $4 \mathrm{a}, \mathrm{c}$ ). Both strains demonstrated faster glucose consumption and higher level of ethanol production than those of DMKU 3-1042. DMKU 3-1042 appeared to quickly convert ethanol to acetate after $12 \mathrm{~h}$. Maximum ethanol concentrations of X-17.2b, X-17 and DMKU 3-1042 were $10.72 \mathrm{~g} \cdot \mathrm{L}^{-1}$, 
$10 \mathrm{~g} \cdot \mathrm{L}^{-1}$ and $9.48 \mathrm{~g} \cdot \mathrm{L}^{-1}$, respectively. These results suggest that both of the $C$. tropicalis strains have a resistant xylose metabolism to glucose repression compared to that of $K$. marxianus DMKU 3-1042 and are suitable for ethanol fermentation with lignocellulosic biomass at high temperatures.
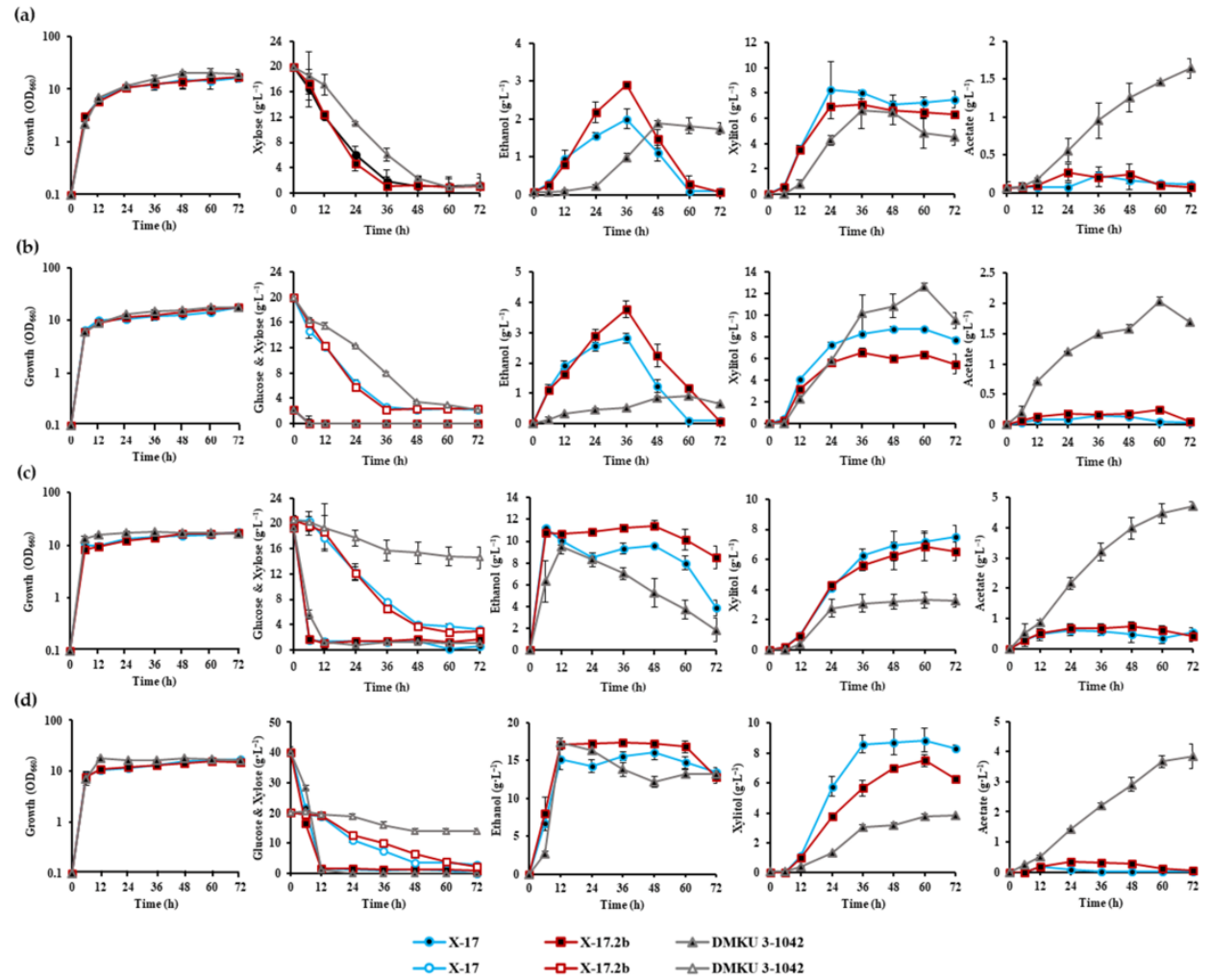

$\begin{array}{ll}\rightarrow-\mathrm{X}-17.2 \mathrm{~b} & \rightarrow \text { DMKU 3-1042 } \\ \rightarrow \mathrm{X}-17.2 \mathrm{~b} & -\triangle-\mathrm{DMKU} \\ 3-1042\end{array}$

Figure 4. Growth and metabolite profiles of C. tropiclis X-17 (filled circles or open circles), adapted strain C. tropicalis X-17.2b (filled squares or open squares) and K. marxianus DMKU 3-1042 (filled triangles or open triangles). Cells were grown in YP media containing (a) $20 \mathrm{~g} \cdot \mathrm{L}^{-1}$ xylose and a mixed sugar medium containing (b) $2 \mathrm{~g} \cdot \mathrm{L}^{-1}$ glucose $+20 \mathrm{~g} \cdot \mathrm{L}^{-1}$ xylose or (c) $20 \mathrm{~g} \cdot \mathrm{L}^{-1}$ glucose $+20 \mathrm{~g} \cdot \mathrm{L}^{-1}$ xylose or (d) $40 \mathrm{~g} \cdot \mathrm{L}^{-1}$ glucose $+20 \mathrm{~g} \cdot \mathrm{L}^{-1}$ xylose at $37^{\circ} \mathrm{C}$ under a shaking condition at $100 \mathrm{rpm}$, and samples were taken at $6 \mathrm{~h}$ and every $12 \mathrm{~h}$ until $72 \mathrm{~h}$ of incubation. In the Glucose \& Xylose panels, filled symbols represent glucose consumption and opened symbols represent xylose consumption. Bars represent the $\pm \mathrm{SD}$ of values from experiments performed in triplicate.

Moreover, the 2:1 ratio of glucose and xylose was examined, on the basis of their existence in lignocellulosic biomass after complete hydrolysis [39-42]. When cells were grown in a medium containing mixed sugars of $40 \mathrm{~g} \cdot \mathrm{L}^{-1}$ glucose and $20 \mathrm{~g} \cdot \mathrm{L}^{-1}$ xylose (Figure $4 \mathrm{~d}$ ), the consumption of glucose and xylose by $\mathrm{X}-17.2 \mathrm{~b}$ was almost the same as that by $\mathrm{X}-17$, and $\mathrm{X}-17.2 \mathrm{~b}$ and DMKU 3-1042 produced a larger amount of ethanol than that produced by $\mathrm{X}-17$ at $12 \mathrm{~h}$ and $24 \mathrm{~h}$, while the xylitol accumulation in $\mathrm{X}-17.2 \mathrm{~b}$ was lower than that in $\mathrm{X}-17$. However, both $\mathrm{C}$. tropicalis strains showed weak glucose repression on xylose utilization compared to DMKU 3-1042. Therefore, these results suggest that adapted $\mathrm{X}-17.2 \mathrm{~b}$ is superior to the parent strain in ethanol production with both a single sugar and mixed sugars and that $\mathrm{X}-17.2 \mathrm{~b}$ may have a great potential for lignocellulosic biomass fermentation.

\subsection{Transcriptome Analysis}

Genome analysis using the Illumina NextSeq 500 platform was performed, but mutation points in X-17.2b were unable to be identified because more than 98,000 putative mutation points were found probably due to the lack of the complete genome sequence of the parent, although the genome data of $\mathrm{X}-17.2 \mathrm{~b}$ and the parent were individually compared 
to those of C. tropicalis MYA-3404 in the NCBI database. We thus carried out transcriptome analysis of $\mathrm{X}-17.2 \mathrm{~b}$ and the parental strain as a control by RNA-Seq using total RNAs prepared from cells grown in YP16D medium at $37^{\circ} \mathrm{C}$ for $12 \mathrm{~h}$, which was the glucoseconsuming phase before a slow-down of glucose consumption (see Figure 2a). Reads per kilobase of exon per million (RPKM) of each gene were estimated as a transcript abundance. The difference of each gene in $\mathrm{X}-17.2 \mathrm{~b}$ from that in the parent was reflected as the ratio of the RPKM value in $\mathrm{X}-17.2 \mathrm{~b}$ to that in the parent. To further explore the transcriptional changes, analysis of differentially expressed genes (DEGs) based on the RNA-Seq data was conducted. DEGs showed significant changes at the transcription level with $\log _{2}$ (fold change) $>2$ and $\log _{2}$ (fold change) $<-2$. Sixty-six genes were significantly up-regulated and 18 genes were significantly down-regulated in X-17.2b (Tables 1 and S1 and Figure S3). KEGG enrichment analysis and GO function enrichment analysis were performed, but no notable results were obtained.

Table 1. Significantly up-regulated genes $\left(\log _{2}>2\right)$ in the adapted strain.

\begin{tabular}{|c|c|c|}
\hline Name & $\log _{2}$ Fold Change & Product \\
\hline CTRG_06057 & 4.95 & Hypothetical protein \\
\hline CTRG_06055 & 4.07 & Hypothetical protein \\
\hline CTRG_06056 & 3.84 & Hypothetical protein \\
\hline CTRG_06100 & 3.63 & Maltose permease \\
\hline CTRG_06311 & 3.31 & tRNA \\
\hline CTRG_00691 & 3.31 & Hypothetical protein \\
\hline CTRG_04447 & 3.23 & Hypothetical protein \\
\hline CTRG_02794 & 3.12 & Hypothetical protein \\
\hline CTRG_03584 & 3.08 & Opaque-phase-specific protein OP4 precursor \\
\hline CTRG_06401 & 3.06 & tRNA \\
\hline CTRG_02358 & 3.05 & Resistance to glucose repression protein 1 \\
\hline CTRG_00749 & 3.02 & Hypothetical protein \\
\hline CTRG_03295 & 2.86 & Hypothetical protein \\
\hline CTRG_06346 & 2.82 & tRNA \\
\hline CTRG_05401 & 2.77 & Ornitine carbamoyltransferase \\
\hline CTRG_05272 & 2.73 & Aga1p \\
\hline CTRG_00349 & 2.71 & Cell wall protein RHD3 \\
\hline CTRG_05402 & 2.61 & Methylglyoxal reductase (NADPH-dependent) \\
\hline CTRG_00711 & 2.60 & White-opaque regulator 3 \\
\hline CTRG_01483 & 2.57 & Hypothetical protein \\
\hline CTRG_05080 & 2.56 & Hypothetical protein \\
\hline CTRG_04732 & 2.55 & Histone $\mathrm{H} 3$ \\
\hline CTRG_01407 & 2.55 & Hypothetical protein \\
\hline CTRG_00808 & 2.54 & Hypothetical protein \\
\hline CTRG_06299 & 2.54 & tRNA \\
\hline CTRG_05490 & 2.52 & Hypothetical protein \\
\hline CTRG_06416 & 2.51 & tRNA \\
\hline CTRG_03294 & 2.51 & Hypothetical protein \\
\hline CTRG_04755 & 2.51 & Hypothetical protein \\
\hline CTRG_06250 & 2.50 & Glucose transporter of major facilitator superfamily \\
\hline CTRG_02210 & 2.42 & $\begin{array}{l}\text { Acetylornithine aminotransferase, mitochondrial } \\
\text { precursor }\end{array}$ \\
\hline CTRG_03885 & 2.29 & Lipase 8 \\
\hline CTRG_00519 & 2.28 & Hypothetical protein \\
\hline CTRG_00291 & 2.28 & Hypothetical protein \\
\hline CTRG_03791 & 2.27 & Hypothetical protein \\
\hline CTRG_00298 & 2.27 & Hypothetical protein \\
\hline CTRG_05031 & 2.25 & Hypothetical protein \\
\hline CTRG_00623 & 2.24 & Hypothetical protein \\
\hline CTRG_02946 & 2.24 & Peroxiredoxin HYR1 \\
\hline
\end{tabular}


Table 1. Cont.

\begin{tabular}{lll}
\hline Name & Log $_{2}$ Fold Change & Product \\
\hline CTRG_06103 & 2.23 & Hypothetical protein \\
CTRG_00350 & 2.22 & Cell wall protein PGA31 \\
CTRG_06301 & 2.20 & tRNA \\
CTRG_05078 & 2.17 & Hypothetical protein \\
CTRG_03785 & 2.16 & Cell wall protein PGA31 \\
CTRG_00604 & 2.15 & Hypothetical protein \\
CTRG_01139 & 2.14 & Hypothetical protein \\
CTRG_02833 & 2.12 & Vacuolar basic amino acid transporter 5 \\
CTRG_00842 & 2.11 & Peroxisomal membrane protein LPX1 \\
CTRG_00266 & 2.10 & Hypothetical protein \\
CTRG_00233 & 2.10 & Hypothetical protein \\
CTRG_02278 & 2.10 & Thiol-specific monooxygenase \\
CTRG_01965 & 2.10 & Hypothetical protein \\
CTRG_01779 & 2.09 & 4-hydroxyphenylpyruvate dioxygenase \\
CTRG_04145 & 2.07 & Hypothetical protein \\
CTRG_00102 & 2.07 & Hypothetical protein \\
CTRG_03730 & 2.07 & NAG4 \\
CTRG_06102 & 2.07 & Hypothetical protein \\
CTRG_02773 & 2.06 & Hypothetical protein \\
CTRG_03597 & 2.05 & Hypothetical protein \\
CTRG_06383 & 2.05 & tRNA \\
CTRG_05709 & 2.04 & Carboxylic acid transporter \\
CTRG_00500 & 2.03 & Hypothetical protein \\
CTRG_06026 & 2.02 & Hypothetical protein \\
CTRG_00590 & 2.02 & Stress response regulator protein 1 \\
CTRG_04524 & 2.01 & Hypothetical protein \\
CTRG_06404 & 2.01 & tRNA \\
\hline & & \\
\hline
\end{tabular}

In order to understand the function of significantly up-regulated gene products, BLAST searching was performed, and the top ranked proteins in C. tropicalis, Candida albicans, Candida dubiniensis and Spathaora passalidarum were listed in Table 1. These proteins were found to be classified as follows: (1) glucose uptake and regulation, including a glucose transporter and negative regulator of glucose repression, (2) stress response, including stress response regulator protein 1, peroxiredoxin HYR1 and NADPH-dependent methylglyoxal reductase, (3) urea cycle and its association, including ornitine carbamolyltransferase and acetylornithine aminotransferease, (4) cell wall proteins, including RHD3, PGA31 encoded by CTRG_00350, PGA31 encoded by CTRG_03785 and AGA1, (5) amino acid degradation, including vacuolar basic amino acid transporter 5 and 4-hydroxyphenylpyruvate dioxygenase, (6) other transporters, including multidrug transporter (NAG4) and carboxylic acid transporter, (7) lipase, including lipase 8 and peroxisomal membrane protein LPX1 and (8) transcriptional regulator, including white-opaque regulator 3 . The up-regulation of a gene for the glucose transporter of the major facilitator superfamily (MFS) may be related to the phenotype of improved utilization capability of high concentrations of glucose (Figure 1). On the other hand, there were 36 genes for hypothetical proteins. To examine whether there were additional MFS members, hydropathy analysis was performed (Figure S2). The analysis revealed that three proteins in those hypothetical proteins might be integral membrane proteins with several possible membrane-spanning segments. The up-regulation of genes for stress response or cell wall proteins may contribute to the multistress tolerance of the adapted strain.

Significantly down-regulated genes included genes for oxidoreductase, fructosebisphosphate aldolase, RNA polymerase II transcription factor B subunit 5, transporter protein SMF1/ESP1, meiotic sister chromatid recombination protein 1, putative diacetyl reductase 2, NAD-dependent alcohol dehydrogenase, glutathione S-transferase 1, respiratory supercomplex factor 2 and sodium transport ATPase 2 (Table S1). The down-regulation of genes for RNA polymerase II transcription factor B subunit 5 or respiratory supercomplex 
factor 2 might reduce transcription and respiratory activity, saving cellular energy for use in stress tolerance.

\section{Discussion}

Generally, C. tropicalis is superior to K. marxianus in the ability to convert xylose to ethanol but inferior in fermentation ability at high glucose concentrations. We thus attempted to improve the inferior property of $C$. tropicalis. Thermotolerant $C$. tropicalis $\mathrm{X}-17$, which was isolated via non-enrichment culture at $37^{\circ} \mathrm{C}$, was subjected to RLCGT for adaptive evolution under a high glucose concentration condition. RLCGT exposes cells to various stresses such as stresses from metabolites including ethanol or organic acids, by-products formed by chemical reactions, nutrient starvation, high temperatures and oxidative stress in addition to large changes in substrate sugar concentration, and it has been shown to be a simple and efficient procedure for the development of robust strains (Pattanakittivorakul et al., submitted). In this study, we first performed RLCGT in the presence of a high glucose concentration and successfully obtained a strain with improved fermentation ability at high glucose concentrations from the cultivation of five different test tubes. Therefore, it is likely that RLCGT is an effective evolutionary adaptation procedure and can be modified with additional factors, such as high sugar concentrations.

$\mathrm{X}-17.2 \mathrm{~b}$, obtained as an adapted strain, was found to have several beneficial properties, including improved tolerance to ethanol, furfural and hydroxymethylfurfural at high temperatures, and enhanced ability for fermentation of high concentrations of glucose and ability for fermentation of xylose (Figures 1-3). The improvement in fermentation capacity was very remarkable. In comparison with the data for the parent, glucose consumption was increased by $15.6 \%$ and ethanol production increased by $30.7 \%$ when cultured in YP16D at $37^{\circ} \mathrm{C}$ and ethanol production was increased by $44.9 \%$ when cultured in YP2X at $37^{\circ} \mathrm{C}$. Transcriptome analysis provided clues for understanding the mechanisms of these properties. Up-regulation of a gene for a glucose transporter may be responsible for increasing glucose consumption ability of the adapted strain. It is possible that some of the putative membrane proteins derived from up-regulated genes also act as glucose transporters or support glucose uptake. Several up-regulated genes for stress response and cell wall proteins may be related to enhanced multistress tolerance of the adapted strain. In addition, it is assumed that up-regulation of genes for amino acid degradation and urea cycle and its association may provide energy and that down-regulation of RNA polymerase II transcription factor B subunit 5 or respiratory supercomplex factor 2 may save energy. On the other hand, most of the up-regulated gene products, except for unknown proteins, can be divided to eight groups (transporter, stress response, cell wall protein, transcriptional regulator, urea cycle, lipase, amino acid metabolism and others) and the finding that each group consisted of two or three members suggests that specific transcriptional factors regulate the expression of these genes.

The fermentation capacity of the adapted strain appears to be superior to those of other $C$. tropicalis strains, including its parental strain. In a medium containing $160 \mathrm{~g} \cdot \mathrm{L}^{-1}$ glucose, C. tropicalis X-17, X-17.2b and DMKU 3-1042 produced ethanol at $1.94 \mathrm{~g} \cdot \mathrm{L}^{-1} \cdot \mathrm{h}^{-1}$, $2.53 \mathrm{~g} \cdot \mathrm{L}^{-1} \cdot \mathrm{h}^{-1}$ and $2.37 \mathrm{~g} \cdot \mathrm{L}^{-1} \cdot \mathrm{h}^{-1}$, respectively (Table 2 ). 
Table 2. Summary of fermentation abilities of C. tropicalis X-17, X-17.2b and K. marxianus DMKU 3-1042 and comparison with those of other C. tropicalis strains.

\begin{tabular}{|c|c|c|c|c|c|c|c|c|c|c|c|}
\hline Strains & Temp. $\left({ }^{\circ} \mathrm{C}\right)$ & $\begin{array}{l}\text { Sugars Conc. } \\
\left(\mathbf{g} \cdot \mathbf{L}^{-1}\right)\end{array}$ & Time (h) & $\begin{array}{l}\text { Sugars } \\
\text { Consumption } \\
\left(\mathrm{g} \cdot \mathbf{L}^{-1}\right)\end{array}$ & $\begin{array}{l}\text { Ethanol } \\
\text { Production } \\
\left(\mathrm{g} \cdot \mathrm{L}^{-1)}\right.\end{array}$ & 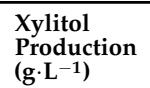 & $\begin{array}{l}\text { Glycerol } \\
\text { Production } \\
\left(\mathrm{g} \cdot \mathrm{L}^{-1)}\right.\end{array}$ & $\begin{array}{l}\text { Acetic Acid } \\
\text { Production } \\
\left(\mathrm{g} \cdot \mathbf{L}^{-1}\right)\end{array}$ & $\begin{array}{l}\text { Ethanol Yield } \\
\left(\mathrm{g} \cdot \mathrm{g}^{-1}\right)\end{array}$ & $\begin{array}{l}\text { Ethanol } \\
\text { Productivity } \\
\left(\mathrm{g} \cdot \mathbf{L}^{-1} \cdot \mathbf{h}^{-1} \text { ) }\right.\end{array}$ & Reference \\
\hline \multirow[t]{5}{*}{ C. tropicalis $\mathrm{X}-17$} & $\begin{array}{l}37 \\
37 \\
37 \\
37\end{array}$ & $\begin{array}{l}\text { Glc } 20 \\
\text { Glc } 160 \\
\text { Xyl 20 } \\
\text { Xyl 50 }\end{array}$ & $\begin{array}{l}6 \\
24 \\
36 \\
60\end{array}$ & \multirow{5}{*}{ 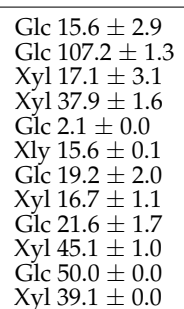 } & $\begin{array}{l}8.2 \pm 0.6 \\
46.5 \pm 0.7 \\
2.0 \pm 0.3 \\
3.1 \pm 0.1\end{array}$ & $\begin{array}{l}- \\
8.0 \pm 0.2 \\
25.2 \pm 0.1\end{array}$ & $\begin{array}{l}\overline{1} 11.4 \pm 0.2 \\
\overline{0} .5 \pm 0.0\end{array}$ & $\begin{array}{l}0.0 \pm 0.0 \\
0.0 \pm 0.0 \\
0.2 \pm 0.0 \\
0.0 \pm 0.0\end{array}$ & $\begin{array}{l}0.4 \pm 0.0 \\
0.3 \pm 0.0 \\
0.1 \pm 0.0 \\
0.1 \pm 0.0\end{array}$ & $\begin{array}{l}1.37 \pm 0.1 \\
1.94 \pm 0.0 \\
0.06 \pm 0.0 \\
0.05 \pm 0.0\end{array}$ & $\begin{array}{l}\text { This study } \\
\text { This study } \\
\text { This study } \\
\text { This study }\end{array}$ \\
\hline & 37 & Glc $2+$ Xyl 20 & 36 & & $2.8 \pm 0.2$ & $8.3 \pm 0.2$ & - & $0.2 \pm 0.0$ & $0.1 \pm 0.0$ & $0.08 \pm 0.0$ & This study \\
\hline & 37 & Glc $20+$ Xyl 20 & 60 & & $8.0 \pm 0.6$ & $7.2 \pm 0.6$ & - & $0.3 \pm 0.2$ & $0.2 \pm 0.0$ & $0.13 \pm 0.0$ & This study \\
\hline & 37 & Glc $20+$ Xyl 50 & 72 & & $10.6 \pm 0.7$ & $30.3 \pm 5.9$ & $0.4 \pm 0.2$ & $0.1 \pm 0.1$ & $0.1 \pm 0.0$ & $0.15 \pm 0.0$ & This study \\
\hline & 35 & Glc $50+$ Xyl 50 & 72 & & $25.2 \pm 0.0$ & $20.0 \pm 0.0$ & - & $0.1 \pm 0.0$ & $0.2 \pm 0.0$ & $0.42 \pm 0.0$ & This study \\
\hline \multirow{6}{*}{$\begin{array}{l}\text { C. tropicalis } \\
\mathrm{X}-17.2 \mathrm{~b}\end{array}$} & 37 & Glc 20 & 6 & Glc $16.2 \pm 4.2$ & $8.1 \pm 0.9$ & - & - & $0.0 \pm 0.0$ & $0.4 \pm 0.0$ & $1.35 \pm 0.1$ & This study \\
\hline & $\begin{array}{l}37 \\
37 \\
37\end{array}$ & $\begin{array}{l}\text { Glc } 160 \\
\text { Xyl } 20 \\
\text { Xyl } 50\end{array}$ & $\begin{array}{l}24 \\
36 \\
60\end{array}$ & \multirow{5}{*}{ 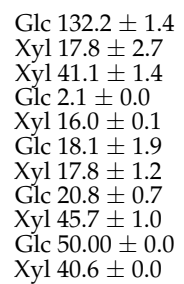 } & $\begin{array}{l}60.7 \pm 2.1 \\
2.9 \pm 0.1 \\
4.4 \pm 0.1\end{array}$ & $\begin{array}{l}\overline{7} .1 \pm 0.4 \\
26.9 \pm 1.5\end{array}$ & $\begin{array}{l}4.5 \pm 0.1 \\
0.8 \pm 0.0\end{array}$ & $\begin{array}{l}0.1 \pm 0.0 \\
0.2 \pm 0.1 \\
0.2 \pm 0.0\end{array}$ & $\begin{array}{l}0.4 \pm 0.0 \\
0.1 \pm 0.0 \\
0.1 \pm 0.0\end{array}$ & $\begin{array}{l}2.53 \pm 0.1 \\
0.08 \pm 0.0 \\
0.07 \pm 0.0\end{array}$ & $\begin{array}{l}\text { This study } \\
\text { This study } \\
\text { This study }\end{array}$ \\
\hline & 37 & Glc $2+$ Xyl 20 & 36 & & $3.8 \pm 0.3$ & $6.6 \pm 0.4$ & - & $0.2 \pm 0.0$ & $0.2 \pm 0.0$ & $0.10 \pm 0.0$ & This study \\
\hline & 37 & Glc $20+$ Xyl 20 & 60 & & $10.1 \pm 0.9$ & $6.9 \pm 1.0$ & - & $0.6 \pm 0.1$ & $0.3 \pm 0.0$ & $0.17 \pm 0.0$ & This study \\
\hline & 37 & Glc $20+$ Xyl 50 & 72 & & $13.6 \pm 0.5$ & $25.4 \pm 2.3$ & $0.4 \pm 0.3$ & $0.7 \pm 0.7$ & $0.2 \pm 0.0$ & $0.19 \pm 0.0$ & This study \\
\hline & 35 & Glc $50+$ Xyl 50 & 72 & & $24.6 \pm 0.9$ & $22.7 \pm 0.0$ & - & $0.2 \pm 0.0$ & $0.2 \pm 0.0$ & $0.40 \pm 0.0$ & This study \\
\hline \multirow{6}{*}{$\begin{array}{l}\text { K. marxianus } \\
\text { DMKU 3-1042 }\end{array}$} & 37 & Glc 20 & 6 & Glc $6.6 \pm 3.2$ & $3.9 \pm 0.7$ & - & - & $0.4 \pm 0.0$ & $0.2 \pm 0.0$ & $0.65 \pm 0.1$ & This study \\
\hline & 37 & Glc $2+$ Xyl 20 & 36 & \multirow{6}{*}{$\begin{array}{l}\text { Glc 132.4 } \pm 1.2 \\
\text { Xyl 12.8 } \pm 2.3 \\
\text { Xly 36.3 } 3.4 \\
\text { Glc 2.1 } 2.0 .0 \\
\text { Xyl 10.3 } \\
\text { Glc 18.3 } 0.2 .9 \\
\text { Xyl } 5.7 \pm 2.9 \\
\text { Glc 22.0 } 2.1 .7 \\
\text { Xyl 15.5 } \\
\text { Xyl 19.2 } 5.5 \\
\text { Glc } \sim 0.0 \\
\text { Xyl } \sim 7 \\
\text { Glc } \sim 50 \\
\text { Xyl 25 }\end{array}$} & $0.5 \pm 0.0$ & $10.2 \pm 1.7$ & - & $1.5 \pm 0.0$ & $0.0 \pm 0.00$ & $0.01 \pm 0.0$ & This study \\
\hline & 37 & Glc $20+$ Xyl 20 & 60 & & $3.8 \pm 0.9$ & $3.3 \pm 0.5$ & - & $4.5 \pm 0.3$ & $0.1 \pm 0.0$ & $0.06 \pm 0.0$ & This study \\
\hline & 37 & Glc $20+$ Xyl 50 & 72 & & $3.3 \pm 1.5$ & $3.5 \pm 1.1$ & $0.9 \pm 0.1$ & $4.6 \pm 0.7$ & $0.1 \pm 0.02$ & $0.05 \pm 0.0$ & This study \\
\hline & 30 & Xyl 20 & 48 & & $1.7 \pm 0.4$ & $2.2 \pm 0.5$ & $\mathrm{NR}$ & $7.2 \pm 0.4$ & $0.1 \pm 0.0$ & $\sim 0.03$ & [14] \\
\hline & 30 & Glc 20: Xyl 20 & 60 & & $\sim 8.0$ & $\sim 2.00$ & NR & $\mathrm{NR}$ & $\sim 0.20$ & $\sim 0.13$ & [14] \\
\hline \multirow{3}{*}{$\begin{array}{l}\text { C. tropicalis } \\
\text { W103 } \\
\text { C. tropicalis } \\
\text { MTCC } 25057\end{array}$} & 35 & Glc $50+$ Xyl 50 & 75 & & $\sim 20$ & NR & NR & NR & $\sim 0.2$ & $\sim 0.26$ & [43] \\
\hline & 32 & Glc 100 & 48 & Glc $\sim 100$ & 36 & NR & NR & NR & $\sim 0.36$ & $\sim 0.75$ & [44] \\
\hline & 32 & Glc $50+$ Xyl 50 & 24 & \multirow{4}{*}{$\begin{array}{l}\text { Glc } 50 \\
\text { Xy } \sim 00 \\
\text { Glc } \sim 00 \\
\text { Xy } 0.7 \\
\text { Glc 27.5 } \\
\text { Xyl 16.7 } \\
\text { NR }\end{array}$} & $18.8 \pm 0.8$ & NR & NR & NR & $\sim 0.2$ & $\sim 0.78$ & [44] \\
\hline \multirow{3}{*}{$\begin{array}{l}\text { C. tropicalis } \\
\text { UFMBX12-a } \\
\text { C. tropicalis } \\
\text { CICC1779 } \\
\text { C. tropicalis M9 }\end{array}$} & 30 & Glc $18+$ Xyl 2 & 30 & & 1.5 & 12 & NR & NR & 0.1 & 0.05 & [45] \\
\hline & 34 & Glc $30+$ Xyl 30 & 72 & & 17.6 & NR & NR & NR & $\sim 0.3$ & $\sim 0.24$ & [46] \\
\hline & 42 & Xyl 50 & 168 & & $\sim 12$ & NR & NR & NR & $\sim 0.2$ & $\sim 0.07$ & {$[8]$} \\
\hline
\end{tabular}

NR not reported. \pm Standard deviation of values from experiments in triplicate. 
The ethanol productivity of $C$. tropicalis $\mathrm{X}-17$ and $\mathrm{X}-17.2 \mathrm{~b}$ was much higher than that of C. tropicalis MTCC 25057, producing ethanol at $0.75 \mathrm{~g} \cdot \mathrm{L}^{-1} \cdot \mathrm{h}^{-1}$ in a medium containing $100 \mathrm{~g} \cdot \mathrm{L}^{-1}$ glucose [44]. At $50 \mathrm{~g} \cdot \mathrm{L}^{-1}$ of xylose, ethanol productivity of $C$. tropicalis $\mathrm{X}-17.2 \mathrm{~b}$ $\left(0.07 \mathrm{~g} \cdot \mathrm{L}^{-1} \cdot \mathrm{h}^{-1}\right)$ was nearly the same as that of C. tropicalis M9 [8]. When glucose and xylose co-existed at the same concentration, $C$. tropicalis $\mathrm{X}-17$ and $\mathrm{X}-17.2 \mathrm{~b}$ consumed about $90 \%$ of xylose within $36-48 \mathrm{~h}$ and converted it to ethanol at $25.2 \mathrm{~g} \cdot \mathrm{L}^{-1}$ and $25.6 \mathrm{~g} \cdot \mathrm{L}^{-1}$, respectively, while C. tropicalis W103 and MTCC 25057 consumed about 50\% (within $75 \mathrm{~h}$ ) and $0 \%$ of xylose, respectively, and converted it to ethanol at $20 \mathrm{~g} \cdot \mathrm{L}^{-1}$ and $18.8 \mathrm{~g} \cdot \mathrm{L}^{-1}$, respectively $[43,44]$. In connection with glucose repression on xylose utilization, $C$. tropicalis $\mathrm{X}-17$ and $\mathrm{X}-17.2 \mathrm{~b}$ consumed $77.8-90.2 \%$ and $80.2-91.4 \%$ of xylose, respectively, in media containing $20 \mathrm{~g} \cdot \mathrm{L}^{-1}$ or $50 \mathrm{~g} \cdot \mathrm{L}^{-1}$ xylose and $2 \mathrm{~g} \cdot \mathrm{L}^{-1}$ or $20 \mathrm{~g} \cdot \mathrm{L}^{-1}$ glucose (Table 2 ). C. tropicalis UFMGBX12 consumed $35 \%$ of xylose in a medium containing $2 \mathrm{~g} \cdot \mathrm{L}^{-1}$ xylose and $18 \mathrm{~g} \cdot \mathrm{L}^{-1}$ glucose [45]. C. tropicalis CICC1779 utilized 55.8\% of xylose in a medium containing $30 \mathrm{~g} \cdot \mathrm{L}^{-1}$ xylose and $30 \mathrm{~g} \cdot \mathrm{L}^{-1}$ glucose [46] and $\mathrm{K}$. marxianus DMKU 3-1042 utilized 35\% of xylose in a medium containing $20 \mathrm{~g} \cdot \mathrm{L}^{-1}$ xylose and $20 \mathrm{~g} \cdot \mathrm{L}^{-1}$ glucose [14]. Therefore, it is likely that $C$. tropicalis $\mathrm{X}-17$ and $\mathrm{X}-17.2 \mathrm{~b}$ are less sensitive in xylose utilization to glucose repression.

This study provided one adapted strain of C. tropicalis via RLCGT as an effective evolutionary adaptation procedure. The strain can ferment a high concentration of glucose more efficiently than can the parental strain or other $C$. tropicalis strains reported. The adapted strain gained multistress tolerance including efficient xylose utilization under glucose repression. These beneficial properties may be useful for industrial ethanol production using lignocellulosic biomass as a substrate.

Supplementary Materials: The following supporting information can be downloaded at: https: / / www.mdpi.com/article/10.3390/en15020561/s1, Figure S1: Schematic diagram of RLCGT for C. tropicalis X-17. C. tropicalis X-17 was cultured in five tubes in parallel in a 5-mL YP liquid medium containing $200 \mathrm{~g} \cdot \mathrm{L}^{-1}$ of glucose under a shaking condition at $100 \mathrm{rpm}$ for 7 days and the cultivation was repeated with gradually increasing temperature from $40{ }^{\circ} \mathrm{C}$ to $44.5^{\circ} \mathrm{C}$. At each step, cells were transferred to a fresh medium at the initial $\mathrm{OD}_{660}$ value of 0.1 . Figure S2: Hydropathy analysis of four hypothetical proteins of which genes were up-regulated in X-17.2b. Hydropathy profiles of a glucose transporter encoded by CTRG_06250 (a), a hypothetical protein encoded by CTRG_06056 (b), a hypothetical protein encoded by CTRG_00691 (c) and a hypothetical protein encoded by CTRG_01139 (d) are shown. Hydropathy analysis was performed by the method of Kyte and Doolittle [36]. Figure S3: Volcano plots of differentially expressed genes (DEGs) of adapted strain $\mathrm{X}-17.2 \mathrm{~b}$ versus the parental strain $\mathrm{X}-17$ at $37^{\circ} \mathrm{C}$ for $12 \mathrm{~h}$. Genes with adjusted $p$-values less than 0.01 and $\log _{2}$ (fold change) values greater than 2 and less than -2 were assigned as genes with differential expression. Red symbols, significantly up-regulated genes; blue symbols, significantly down-regulated genes. Table S1: Significantly down-regulated genes $\left(\log _{2}<-2\right)$ in the adapted strain.

Author Contributions: K.P. performed phenotypic analysis, analyzed data, and wrote the original manuscript. K.P. and M.N. performed adaptation experiments. C.K.-O., N.V., M.C., V.S. and S.B. screened and characterized the parental strain. M.M. performed genome analysis. T.K. gave advice for genome and transcriptome analyses. S.L. gave advice for enrichment culture. M.Y. organized the study and revised the manuscript. All authors have read and agreed to the published version of the manuscript.

Funding: This work was carried out under the e-ASIA Joint Research Program, which was granted by Japan Science and Technology Agency (JPMJSC16E5) (TK and MY).

Institutional Review Board Statement: Not applicable.

Informed Consent Statement: Not applicable.

Data Availability Statement: All data are reported in this manuscript.

Acknowledgments: We thank Kazunobu Matsushita, Toshiharu Yakushi and Naoya Kataoka for their helpful discussion.

Conflicts of Interest: The authors declare no conflict of interest. 


\section{References}

1. Moreno, A.D.; Carbone, A.; Pavone, R.; Olsson, L.; Geijer, C. Evolutionary engineered Candida tropicalis exhhibits improved xylose utilization and robustness to lignocelluloses-derived inhibitors and ethanol. Appl. Microbiol. Biotechnol. 2019, 103, 1405-1406. [CrossRef]

2. Hoekman, S.K. Biofuels in the U.S.-challenges and opportunities. Renew. Energy 2009, 34, 14-22. [CrossRef]

3. Li, G.; Lu, Z.; Zhang, J.; Li, H.; Zhou, Y.; Zayan, A.M.I.; Huang, Z. Life cycle assessment of biofuel production from microalgae cultivated in anaerobic digested wastewater. Int. J. Agric. Biol. 2020, 13, 241-246. [CrossRef]

4. Li, G.; Bai, X.; Huo, S.; Huang, Z. Fast pyrolysis of LERDADEs for renewable biofuels. IET Renew. Power Gener. 2020, 14, 959-967. [CrossRef]

5. Manyuchi, M.M.; Chiutsi, P.; Mbohwa, C.; Muzenda, E.; Mutusva, T. Bio ethanol from sewage sludge: A bio fuel alternative. S. Afr. J. Chem. Eng. 2018, 25, 123-127. [CrossRef]

6. Patel, A.; Shah, A.R. Integrated lignocellulosic biorefinery: Gateway for production of second generation ethanol and value assed products. J. Bioresour. Bioprod. 2021, 6, 108-128. [CrossRef]

7. Hamouda, H.I.; Nassar, H.N.; Madian, H.R.; Amr, S.A.; EI-Gendy, N.S. Statistical optimization of batch ethanol fermentation of sugarcane molasses by Candida tropicalis strain HSC-24. Int. J. Chemtech. 2015, 8, 878-889.

8. Nweze, J.E.; Ndubuisi, I.; Murata, Y.; Omae, H.; Ogbonna, J.C. Isolation and evaluation of xylose-fermening thermotolerant yeasts for bioethanol production. Biofuels 2019, 12, 961-970. [CrossRef]

9. Rodrussamee, N.; Sattayawat, P.; Yamada, M. Highly efficient conversion of xylose to ethanol without glucose repression by newly isolated thermotolerant Spathaspora passalidarum CMUWF1-2. BMC Microbiol. 2018, 18, 73. [CrossRef] [PubMed]

10. Panwar, N.L.; Kaushik, S.C.; Kothari, S. Role of renewable energy sources in environmental protection: A review. Renew. Sust. Energ. Rev. 2011, 15, 1513-1524. [CrossRef]

11. Chen, H.Z.; Fu, X.G. Indrustrial technologies for bioethanol production from lignocellulosic biomass. Renew. Sustain. Energy Rev. 2016, 57, 468-478. [CrossRef]

12. Mano, M.C.R.; Neri-Numa, I.A.; Silva, J.B.; Paulino, B.N.; Pessoa, M.G.; Pastore, G.M. Oligosaccharide biotechnology: An approach of prebiotic revolution on the industry. Appl. Microbiol. Biotechol. 2018, 102, 17-37. [CrossRef] [PubMed]

13. Triwahyuni, E.; Muryanto; Sudiyani, Y.; Abimanyu, H. The effect of substrate loading on simultaneous saccharification and fermentation process for bioethanol production from oil palm empty fruit bunches. Energy Procedia. 2015, 68, 138-146. [CrossRef]

14. Nitiyon, S.; Keo-oudone, C.; Murata, M.; Lertwattanasakul, N.; Limtong, S.; Kosaka, T.; Yamada, M. Efficient conversion of xylose to ethanol by stress-tolerant Kluyveromyces marxianus BUNL-21. SprigerPlus 2016, 5, 185. [CrossRef]

15. Nguyen Tran, P.H.; Ko, J.K.; Gong, G.; Um, Y.; Lee, S.M. Improved simultaneous co-fermentation of glucose and xylose by Saccharomyces cerevisiae for efficient lignocellulosic biorefinery. Biotechnol. Biofuels 2020, 13, 12. [CrossRef]

16. Kim, D. Physico-chemical conversion of lignocellulose: Inhibitor effects and detoxification strategies: A mini review. Molecules 2018, 23, 309. [CrossRef] [PubMed]

17. Sánchez, Ó.J.; Cardona, C.A. Trends in biotechnological production of fuel ethanol from different feedstocks. Bioresour. Technol. 2008, 99, 5270-5295. [CrossRef]

18. Gibson, B.R.; Lawrence, S.J.; Leclaire, J.P.R.; Powell, C.D.; Smart, K.A. Yeast responses to stresses associated with industrial brewery Handling. FEMS Microbiol. Rev. 2007, 31, 535-569. [CrossRef] [PubMed]

19. Zhao, X.Q.; Bai, F.W. Mechanisms of yeast stress tolerance and its manipulation for efficient fuel ethanol production. J. Biotechnol. 2009, 144, 23-30. [CrossRef]

20. Puligundla, P.; Smogrovicova, D.; Obulam, V.S.R.; Ko, S. Very high gravity (VHG) ethanolic brewing and fermentation: A research update. J. Ind. Microbiol. Biotechnol. 2011, 38, 1133-1144. [CrossRef]

21. Auesukaree, C. Molecular mechanisms of the yeast adaptive response and tolerance to stresses encountered during ethanol fermentation. J. Biosci. Bioeng. 2017, 124, 133-142. [CrossRef]

22. Azhar, S.H.M.; Abdulla, R.; Jambo, S.A.; Marbawi, H.; Gansau, J.A.; Faik, A.A.M.; Rodrigues, K.F. Yeast in sustainable bioethanol production: A review. Biochem. Biophys. Rep. 2017, 10, 52-61.

23. Kamoldeen, A.A.; Lee, C.K.; Abdullah, W.N.W.; Leh, C.P. Enhanced ethanol production from mild alkali-treated oil-palm empty fruit bunches via co-fermentation of glucose and xylose. Renew. Energy 2017, 107, 113-123. [CrossRef]

24. Greetham, D.; Hart, A.J.; Tucker, G.A. Presence of low concentrations of acetic acid improves yeast tolerance to hydroxymethylfurfural (HMF) and furfural. Biomass Bioenergy 2016, 85, 53-60. [CrossRef]

25. Cheng, N.G.; Hasan, M.; Kumoro, A.C.; Ling, C.F.; Tham, M. Production of ethanol by fed-batch fermentation. Pertanika J. Sci. Technol. 2009, 17, 399-408.

26. Alba, M.G.; Parra, M.A.M.; Olmo, M.D. Response of yeast cells to high glucose involves molecular and physiological difference when compared to other osmostress conditions. FEMS Yeast Res. 2015, 15, fov039. [CrossRef] [PubMed]

27. Wang, L.; Li, B.; Wang, S.P.; Xia, Z.Y.; Gou, M.; Tang, Y.Q. Improving multiple stress tolerance of a flocculating industrial Saccharomyces cerivisiae strain by random mutagenesis and hybridization. Process Biochem. 2021, 102, 275-285. [CrossRef]

28. Limtong, S.; Sringiew, C.; Yongmanitchai, W. Production of fuel ethanol at high temperature from sugar cane juice by a newly isolated Kluyveromyces marxianus. Bioresour. Technol. 2007, 17, 3367-3374. [CrossRef]

29. Sambrook, J.; Russell, D.W. Preparation and analysis of eukaryotic genomic DNA. In Molecular Cloning a Laboratory Manual, 3rd ed.; Cold Spring Harbor Laboratory Press: New York, NY, USA, 2001; Volume 3, pp. 1-62. 
30. Li, H.; Durbin, R. Fast and accurate short read alignment with burrow-wheeler transform. J. Bioinform. 2009, 25, 1754-1760. [CrossRef]

31. McKenna, A.; Hanna, M.; Banks, E.; Sivachenko, A.; Cibulskis, K.; Kernytsky, A.; Garimella, K.; Altshuler, D.; Gabriel, S.; Daly, M.; et al. The Genome Analysis Toolkit: A MapReduce framework for analyzing next-generation DNA sequencing data. Genome Res. 2010, 20, 1297-1303. [CrossRef]

32. Nurcholis, M.; Nitiyon, S.; Suprayogi; Rodrussamee, N.; Lertwattanasakul, N.; Limtong, S.; Kosaka, T.; Yamada, M. Functional analysis of Mig1 and Rag5 as expressional regulators in thermotolerant yeast Kluyveromyces marxianus. Appl. Microbiol. Biotechnol. 2019, 103, 395-410. [CrossRef]

33. Lertwattanasakul, N.; Kosaka, T.; Hosoyama, A.; Suzuki, Y.; Rodrussamee, N.; Matsutani, M.; Murata, M.; Fujimoto, N.; Suprayogi; Tsuchikane, K.; et al. Genetic basis of the highly efficient yeast Kluyveromyces marxianus: Complete genome sequence and transcriptome analyses. Biotechnol. Biofuels 2015, 8, 47. [CrossRef] [PubMed]

34. Kim, I.S.; Kim, Y.S.; Kim, H.; Jin, I.; Yoon, H.S. Saccharomyces cerevisiae KNU5377 stress response during high-temperature ethanol fermentation. Mol. Cells. 2013, 35, 210-218. [CrossRef] [PubMed]

35. Andars, S.; Huber, W. Differential expression analysis for sequence count data. Nat. Preced. 2010, 11, R106.

36. Kyte, J.; Doolittle, R.F. A simple method for displaying the hydropathic character of a protein. J. Mol. Biol. 1982, 157, 105-132 [CrossRef]

37. Eisenberg, D.; Schwarz, E.; Komaromy, M.; Wall, R. Analysis of membrane and surface protein sequences with the hydrophobic moment plot. J. Mol. Biol. 1984, 179, 125-142. [CrossRef]

38. Rodrussamee, N.; Lertwattanasakul, N.; Hirata, K.; Suprayogi; Limtong, S.; Kosaka, T.; Yamada, M. Growth and ethanol fermentation ability on hexose and pentose sugars and glucose effect under various conditions in thermotolerant yeast Kluyveromyces marxianus. Biomass Bioenergy 2011, 90, 1573-1586. [CrossRef]

39. Guragain, Y.N.; Chitta, D.; Karanjikar, M.; Vadlani, P.V. Appropriate lignocellulosic biomass processing strategies for efficient 2,3-butanediol production from biomass derived sugars using Bacillus licheniformis DSM 8785. Food Bioprod. Process. 2017, 104, 147-158. [CrossRef]

40. Ji, X.J.; Huang, H.; Du, J.; Zhu, J.G.; Ren, L.J.; Li, S.; Nie, Z.K. Development of an industrial medium for economical 2,3-butanediol production through co-fermentation of glucose and xylose by Klebsiella oxytoca. Bioresour. Technol. 2009, 100, 5214-5218. [CrossRef]

41. Yan, L.; Zhang, H.; Chen, J.; Lin, Z.; Jin, Q.; Jia, H.; Huang, H. Dilute sulfuric acid cycle spray flow-through pretreatment of corn stover for enhancement of sugar recovery. Bioresour. Technol. 2009, 100, 1803-1808. [CrossRef]

42. Stephanopoulos, G. Challenges in engineering microbes for biofuels production. Science 2007, 315, 801-804. [CrossRef]

43. Cheng, K.K.; Wu, J.; Lin, Z.N.; Zhang, J.A. Aerobic and sequential anaerobic fermentation to produce xylitol and ethanol using non-detoxified acid pretreated corncob. Biotechnol. Biofuels 2014, 7, 166. [CrossRef] [PubMed]

44. Mattam, A.J.; Kuila, A.; Suralikerimath, N.; Choudary, N.; Rao, P.V.C.; Velankar, H.R. Cellulolytic enzyme expression and simultaneous conversion of lignocellulosic sugars into ethanol and xylitol by a new Candida tropicalis strain. Biotechnol. Biofuels 2016, 9, 157. [CrossRef] [PubMed]

45. Antunes, F.A.F.; Thomé, L.C.; Santos, J.C.; Ingle, A.P.; Costa, C.B.; Anjos, V.D.; Bell, M.J.V.; Rosa, C.A.; Silva, S.S. Multi-scale study of the integrated use of the carbohydrate fraction of sugarcane bagasse for ethanol and xylitol production. Renew. Energy 2021, 163, 1343-1355. [CrossRef]

46. Li, X.; Deng, Y.; Yang, Y.; Wei, Z.; Cheng, J.; Cao, L.; Mu, D.; Luo, S.; Zheng, Z.; Jiang, S.; et al. Fermentation process and metabolic flux of ethanol production from the detoxified hydrolyzate of cassava residue. Microbiology 2017, 8, 1603. [CrossRef] [PubMed] 